\section{Strukturert om fysiologi for sykepleiestudenter}

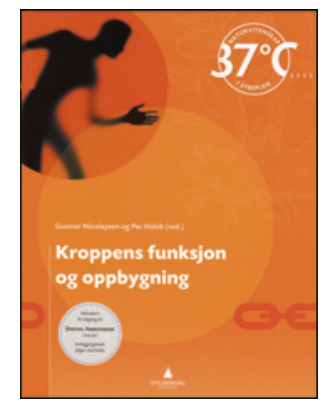

Gunnar Nicolaysen, Per Holck, red. Kroppens funksjon og oppbygning 325 s, tab, ill. Oslo: Gyldendal Akademisk, 2013. Pris NOK 790

ISBN 978-82-05-32362-9

Boken er den første av fem bøker som til sammen danner en kunnskapspakke beregnet på bachelorutdanningen i sykepleie. Kunnskapspakken har fått tittelen $37^{\circ} \mathrm{C}$ og dekker pensumskravene innen anatomi og fysiologi, sykdomslære, farmakologi og mikrobiologi. Pakken har en egen nettside. Hver bok har egen side på nettsiden som både supplerer boken og har interaktive oppgaver knyttet til hvert kapittel. Oppgavene er av stigende vanskelighetsgrad og er relevante for både praksis og eksamen.

Kroppen funksjon og oppbygning er delt i tre hoveddeler. I del 1, Celler og vev, beskriver forfatterne hvordan ulike celler i kroppen fungerer og er bygd opp. I del 2 fokuserer de på organenes funksjon og oppbygning. Her omtales de enkelte organsystemene med vekt på å få frem hvordan organene fungerer. Del 3 inneholder en omtale av hvordan kroppens indre miljø reguleres, for eksempel gjennomgås energiomsetning og syre-base-balanse. Det er også et eget kapittel om fosterutvikling.

Redaktørene er viktige bidragsytere. Gunnar Nicolaysen er professor emeritus etter mange år som professor i fysiologi. Per Holck er også professor emeritus og har biologisk antropologi og rettsantropologi som spesialfelt. Boken bærer også preg av at de har fått bidrag fra kolleger som har solid bakgrunn innen ulike fagfelt.

Utformingen er tiltalende med strukturert og logisk oppbygning. Illustrasjoner er rikelige, gode og hjelper leseren i forståelsen av stoffet. Nye ord og begreper blir forklart på en god måte. Første kapittel oppleves noe tungt å lese. Her synes det som om forfatteren ønsker å formidle komplekse prosesser på en lettfattelig måte. Det kan imidlertid tenkes at lesere uten tidligere innføring i temaet vil finne dette kapitlet vanskelig tilgjengelig. De øvrige delene er lettere og inspirerende å komme gjennom. Totalt sett er dette en velskrevet bok som sikkert vil være velegnet for både målgruppen og andre som måtte ha behov for innføring i dette fagfeltet.

\section{Marit Grønning}

Overlege, Yrkesmedisinsk avdeling

Haukeland universitetssykehus

\section{Kvinners rett til utdanning når kvinners liv og helse står på spill}

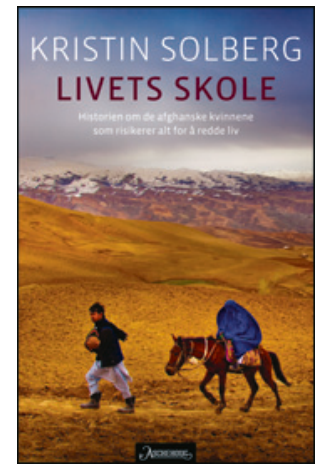

\author{
Kristin Solberg \\ Livets skole \\ Historien om de afghanske kvinnene \\ som risikerer alt for å redde liv. $305 \mathrm{~s}$. \\ Oslo: Aschehoug, 2013. Pris NOK 349 \\ ISBN 978-82-03-29341-2
}

Vi har hørt historier om kvinners stilling i Afghanistan. Vi vet at de har verdens høyeste tall på mødre- og barnedødelighet, og at kvinner har lite bevegelsesrom. Alle vet hva en burka er, og alle vet at jenter i Afghanistan ofte nektes skolegang.

Norsk innsats for å støtte oppbyggingen av jordmorutdanning i Afghanistan er mindre kjent, men uten lokale aktører ville det ikke latt seg gjøre.

Dette er historien om en jordmorskole, en dedikert lærer, noen elever med spesielle livsvilkår og om gruppeutdanning av jenter innenfor murene i en liten by. Forfatteren er en ung journalist som har vært i landet, observert undervisningen og intervjuet lærere og elever. Rammen rundt er å fortelle en historie om hvordan det går eller ikke går - å drive en aktiv jordmorutdanning $i$ et land hvor få synes dette er meningsfylt, og hvor det også er farlig å leve.

Det er spennende og interessant stoff. Boken gir små glimt inn $i$ en virkelighet som vi ante fantes, men ikke har fått så detaljert beskrevet før. Forfatteren har opplagt hatt et stort engasjement og skriver tidvis godt. Dramaturgien er dog litt oppstykket, noen ganger ender kapitlene mer som en kriminalroman med ubesvarte spørsmål, enn som en dokumentarbok. Det er sikkert et slags «les videre»-grep, men jeg synes ikke det fungerer så bra. Jeg synes også at det er vanskelig å skille ut hva som er forfatterens egne observasjoner, og hva som er observasjoner gjort av informantene.

Det som blir fortalt, er viktig, men jeg savner en samfunnsvitenskapelig analyse av konteksten. Noen av helsespørsmålene som tas opp, er fortalt i et «legmannsspråk» og kan fremstå som litt banale for lesere med helsefaglig bakgrunn. Fødselsutfordringene er jo generelle, men det spesifikke i Afghanistan kommer ikke så tydelig frem.

På den annen side er persongalleriet interessant. Legen, som er den bærende figuren, fremstår litt vel ideologisk og endimensjonal, selv om hun er dedikert. Grenseoppgangen mellom den hun er, og litt lettkjøpte klisjeer, er hårfin. Historiene til enkelte av de «forfulgte» er spennende og ubehagelige, og inviterer til ettertanke.

Alt $i$ alt er dette en lesbar bok som sier oss noe om hvor viktig søkelys på helse er, og hvor vanskelig det kan være å være kvinne. Kanskje burde flere av oss engasjere oss i idealistisk arbeid. Verden trenger det.

\footnotetext{
Johanne Sundby

Professor, Seksjon for internasjonal helse

Universitetet i Oslo
} 